\title{
EVALUATION OF EPPAWALA ROCK PHOSPHATE AS A PHOSPHORUS SUPPLEMENT IN DIETS FOR GROWING CHICKENS AND PIGS
}

\author{
G. A. P. GANEGODA, S. P. GUNARATNE \\ Veterinary Research Institute, Gannoruwa, Peradeniya, Sri Lanka
}

AND

A. A. P. GUNATILAKE

Veterinary Investigation Centre, Welisara, Ragama, Sri Lanka.

(Date of receipt : 9.4.86)

(Date of acceptance : 30.12 .86 )

\begin{abstract}
In poultry and pig feeding, it is important to ensure an adequate intake of phosphorus $(\mathrm{P})$ in a readily available form especially during the growing stage. A chick assay and a pig experiment were conducted to evaluate Eppawala rock phosphate (ERP) as a dietary $P$ supplement for these animal species. In the 12-day chick assay, 75 eight-day-old crossbred male chicks divided into 15 units were used to determine the available $\mathrm{P}$ content of ERP by the slope-ratio technique; $\mathrm{KH}_{2} \mathrm{PO}_{4}$ was used as the reference $P$ supplement and tibia ash, the response criterion. In the pig experiment, 24 freshly weaned Large White pigs arranged in a randomized complete block design with eight pigs per treatment were individually housed and fed diets providing single levels of dicalcium phosphate (DCP), ERP or no P supplement; evaluation was based on growth performance and bone composition. The results showed that ERP contained little or no available $P$ for growing chickens and that it was significantly inferior to DCP as a $P$ supplement for growing pigs $(p<0.01)$. Dietary inclusion of ERP appeared to be more harmful than noninclusion of a $P$ supplement; this effect was attributed to fluorine present in ERP. Even though ERP as such was not, defluorinated ERP would be quite comparable with DCP which is now being imported in large quantities for $P$ supplementation of animal diets. ERP has also been found to be unsuitable for direct application to crops, and large quantities of phosphate fertilizer have to be imported annually. These facts taken together warrant the installation of rock phosphate processing plants for optimal utilization of ERP in animal and crop production.
\end{abstract}

\section{Introduction}

Practical diets for poultry and pigs are based on cereals and oilseed meals. Since these feedingstuffs do not provide adequate amounts of calcium $(\mathrm{Ca})$ and phosphorus (P), it is usual to include $\mathrm{Ca}$ and $\mathrm{P}$ supplements in such diets. The commonly used $\mathrm{P}$ supplements e.g. dicalcium phosphate (DCP) are expensive. Nevertheless, the diets for growing poultry and pigs must contain 
adequate levels of $\mathrm{P}$ in a readily available form commensurate with their rapid growth.

Rock phosphates from the principal deposits of the world have been evaluated by many workers for $P$ supplementation of diets for farm animals. ${ }^{10}$ The variance of the results of those evaluations can be attributed partly to the differences in the available $P$ and fluorine (F) contents of the various rock phosphates.

A huge deposit of light brown rock phosphate of the chlorfluorapatite type was discovered by the Geological Survey Department at Eppawala in 1971. This deposit is being exploited by the State Mining \& Mineral Development Corporation to produce unprocessed phosphatic fertilizer; but none of it is being utilized in animal feeding. Defluorination improves the feeding value of rock phosphates by eliminating the hazard of $\mathrm{F}$ toxicity as well as by increasing the biologically available $\mathrm{P}$ content. However, defluorinating facilities are not available in Sri Lanka. The chick assay and the pig experiment reported herein were therefore thought to be a necessary first step for the proper utilization of Eppawala rock phosphate (ERP) in animal production.

\section{Experimental}

\subsection{Phosphorus Supplements}

ERP ground to pass through $0.15 \mathrm{~mm}$ mesh was procured from the State Mining and Mineral Development Corporation; it contained $23.0 \% \mathrm{Ca}$ and $14.7 \%$ P. DCP procured from the Asia Glues and Chemicals Ltd, Madurai, India for use as the control $\mathrm{P}$ supplement in the pig experiment contained $27.5 \% \mathrm{Ca}$ and $17.8 \% \mathrm{P}$. Atomic absorptiometry and colorimetric vanadomolybdate procedure were used for the determination of $\mathrm{Ca}$ and $\mathrm{P}$, respectively. Potassium dihydrogen orthophosphate $\left(\mathrm{KH}_{2} \mathrm{PO}_{4}\right)$ of analytical reagent grade was used as the reference $P$ supplement in the chick assay.

\subsection{Chick Assay}

A batch of 125 crossbred (Hubbard Golden Comet) males procured as dayold chicks were fed a conventional maize-soya bean meal starter diet for 7 days. They were then fasted for $12 \mathrm{~h}$ and after discarding the heaviest and the lightest, 75 of them were divided equally into 15 experimental units (penlots) of similar mean body weights. The penlots were housed in decks of raised wire-floor battery cages in a room with continuous lighting and a temperature of $25^{\circ} \mathrm{C}$ to $27^{\circ} \mathrm{C}$ and randomly assigned to five dietary trea- 
ments. Food and distilled water were provided ad libitum for 12 days.

The five diets were as follows: A purified basal diet supplying $0.10 \% \mathrm{P}$ from the reference $\mathrm{P}$ supplement was prepared according to the formula of Corley et $a l^{5}$ This minimal level of $\mathrm{P}$ has been shown to be adequate to prevent chick mortality. Two reference $P$ diets to contain 0.05 and $0.10 \%$ additional $\mathrm{P}$ and two ERP diets to contain 0.10 and $0.15 \%$ additional $\mathrm{P}$ were prepared by substituting appropriate amounts of the respective $\mathrm{P}$ supplements for maize starch weight for weight in the basal diet.

At the conclusion of the 12-day assay period, each chick was weighed and killed by bleeding. The left tibiae of the chicks from each penlot were freed from adherent tissues after steaming for $5 \mathrm{~min}$, defatted with chloroform-methanol $(2: 1 \mathrm{v} / \mathrm{v})$ and ashed at $600^{\circ} \mathrm{C}$ for $36 \mathrm{~h}$.

Data on $\mathbf{P}$ intake and tibia ash of the penlots that were fed the basal and reference $P$ diets were subjected to linear regression. The reference $P$ response equation so obtained was applied to the penlots that were fed the ERP diets to calculate the fraction of tibia ash due to $P$ intake from the reference $P$ supplement; the remaining tibia ash was attributed to $P$ intake from ERP. Data on ERP intake and tibia ash due to ERP could then be used to obtain the ERP response equation. The available P content of ERP could be estimated by dividing the regression coefficient of the ERP response equation by that of the reference $P$ response equation (slope-ratio technique).

\subsection{Pig Experiment}

Twenty-four freshly weaned Large White pigs were arranged in four blocks of three littermate males and four blocks of three littermate females, and assigned to three dietary regimes in a randomized complete block design. The pigs were individually housed on concrete floors.

Table 1 gives the ingredient composition and nutrient contents of the diats used for two-stage feeding. The positive control and test diets contained supplemental P as DCP and ERP, respectively, while the negative control diet did not contain any supplemental P. Daily feed allowance for each pig, adjusted at weekly intervals according to body weight, was computed from the equation

$$
\mathrm{Y}=0.44+0.385 \mathrm{X}
$$

where $\mathrm{X}$ was the body weight and $\mathrm{Y}$ the daily feed allowance, both in $\mathrm{kg}$. The daily allowance was fed in two meals after moistening with water at the rate of 2.51 per $\mathrm{kg}$ of feed. 


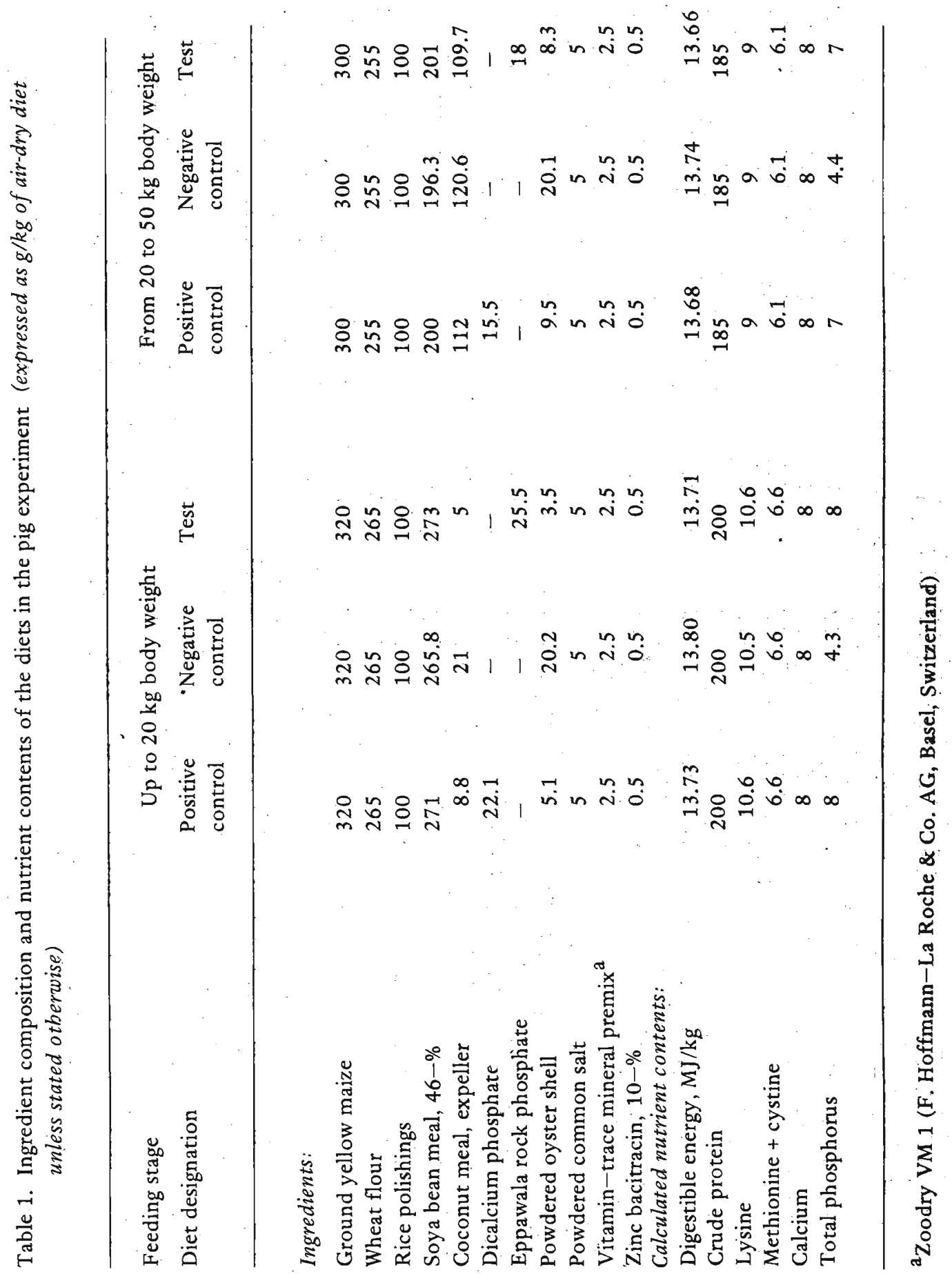


Each pig was slaughtered when it reached $50 \mathrm{~kg}$ in body weight and its left fourth metacarpal bone was dissected out. The individual bones were defatted and ashed as in the chick assay; their dry fat-free weights were recorded before ashing. Bone $\mathrm{Ca}$ and $\mathrm{P}$ were determined as in the case of the $\mathrm{P}$ supplements. Response to dietary $\mathrm{P}$ supplementation was judged by time taken to reach $50 \mathrm{~kg}$ in body weight, mean daily feed intake, mean daily weight gain, feed:gain ratio and bone composition. Observations on each criterion were subjected to analysis of variance; differences between treatment means were assessed by Duncan's new multiple range test at $1-\%$ significance level.

\section{Results}

\subsection{Chick Assay}

The results of the chick assay for the estimation of available $P$ in ERP is summarised in Table 2. There was virtually no accumulation of tibia ash attributable to $\mathrm{P}$ intake from ERP, indicating that the available $\mathrm{P}$ content of ERP for growing chickens was virtually nil.

\subsection{Pig Experiment}

Table 3 gives a summary of the results of the pig experiment. The pigs on the ERP-supplemented dietary regime took a longer time to attain the final weight and consumed more feed per unit weight gained than those on the DCP-supplemented dietary regime $(p<0.01)$. Inclusion of ERP as a dietary $P$ supplement appeared to be worse than noninclusion of a $\mathrm{P}$ supplement. -However, retention of $\mathrm{Ca}$ and $\mathrm{P}$ in bone was not affected by the dietary treatments.

\section{Discussion}

The principal rock phosphate deposits of the world can be broadly typed as continental and island deposits. Continental deposits such as those occurring in North Africa and North America contain 3 to $4 \%$ F, whereas deposits found in the Pacific and Indian Ocean islands generally contain only half that or even less. ${ }^{15}$ Island deposits had been generally regarded as safe for $\mathrm{P}$ supplementation of cattle, pig and poultry diets. 13

However, it is evident from the results that ERP is virtually ineffective for $P$ supplementation of diets for growing poultry, Since ERP contains about $2 \% \mathrm{~F},{ }^{2}$ the ERP diets fed during the starter and grower stages of the pigs (Table 1) must have contained at least 510 and $360 \mathrm{ppm} \mathrm{F}$, respectively. That these levels are deleterious to pig performance is indicated by the fact 


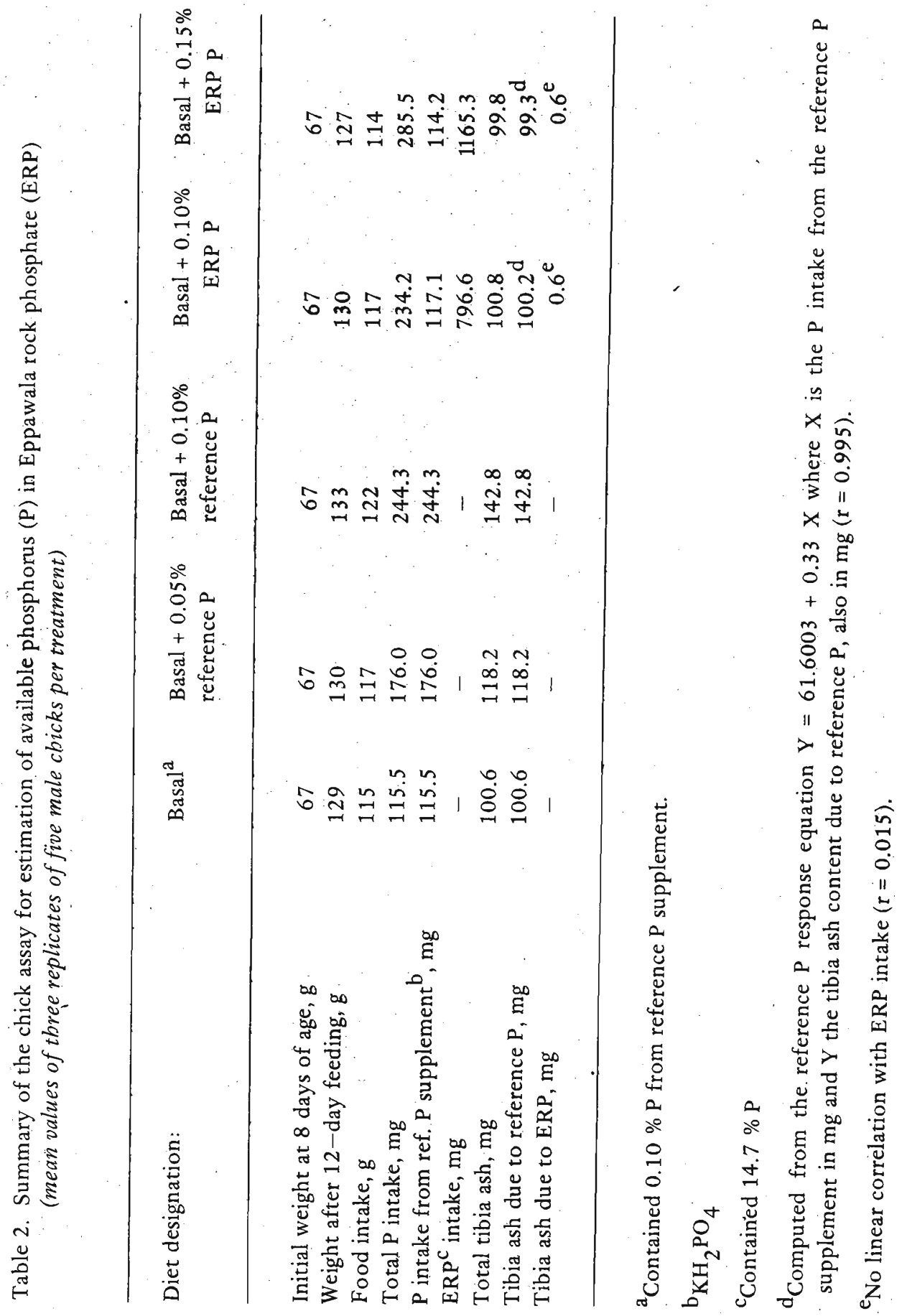


Table 3. Growth performance and bone composition of pigs fed diets with dicalcium phosphate (DCP), Eppawala rock phosphate (ERP) or no phosphorus supplement from weaning to $50-\mathrm{kg}$ body weight (mean values of four males and four females per treatment in randomised complete block design)

\begin{tabular}{|c|c|c|c|c|c|}
\hline \multirow[b]{2}{*}{ Phosphorus supplement: } & \multirow{2}{*}{$\begin{array}{c}\text { Positive } \\
\text { control } \\
\text { DCP }\end{array}$} & \multirow{2}{*}{$\begin{array}{l}\text { Negative } \\
\text { control } \\
\text { None }\end{array}$} & \multirow{2}{*}{$\begin{array}{l}\text { Test } \\
\text { ERP }\end{array}$} & \multirow[t]{2}{*}{$\begin{array}{l}\text { SE of } \\
\text { diff. }\end{array}$} & \multirow[t]{2}{*}{$\begin{array}{l}\mathrm{CV} \\
(\%)\end{array}$} \\
\hline & & & & & \\
\hline Initial wt., kg & 10.4 & 10.5 & 10.4 & & \\
\hline \multicolumn{2}{|c|}{ Time taken to reach $50-\mathrm{kg}$ wet.days $83.1^{\mathrm{a}}$} & $89.3^{\mathrm{a}}$ & $96.3^{\mathrm{b}}$ & 2.1 & 4.9 \\
\hline Mean daily feed intake, $\mathrm{kg}$ & $1.48^{\mathrm{a}}$ & $1.45^{\mathrm{d}}$ & $1.48^{\mathrm{a}}$ & 0.02 & 2.3 \\
\hline Mean daily wt. gain, $\mathrm{kg}$ & $0.49^{\mathrm{a}}$ & $0.45^{\mathrm{ab}}$ & $0.42^{b}$ & 0.01 & 5.6 \\
\hline Feed:gain ratio & $3.02^{\mathrm{a}}$ & $3.28^{\mathrm{ab}}$ & $3.49^{b}$ & 0.12 & $7: 4$ \\
\hline \multicolumn{6}{|l|}{ Left fourth metacarpal: } \\
\hline Fat-free dry wt., $g$ & 6.395 & 6.231 & 6.340 & & \\
\hline Ash, g/kg & $609.4^{\mathrm{a}}$ & $608.0^{\mathrm{a}}$ & $611.0^{\mathrm{a}}$ & 7.2 & 0.3 \\
\hline Calcium, $\mathrm{g} / \mathrm{kg}$ & $234.0^{\mathrm{a}}$ & $232.2^{\mathrm{a}}$ & $232.9^{a}$ & 5.3 & 0.6 \\
\hline Phosphorus, g/kg & $111.0^{\mathrm{a}}$ & $108.6^{\mathrm{a}}$ & $106.7^{\mathrm{a}}$ & 2.9 & 0.7 \\
\hline
\end{tabular}

In a given row, values with different superscripts are significantly different $(p<0.01)$.

Table 4. Maximum safe dietary fluorine levels for different farm animals according to form of fluorine (expressed as $m g / k g d r y$ matter)

Young cattle

Dairy cow

$\begin{array}{ll} & 30 \\ 30-50 & 65-100 \\ 40-50 & 65-100 \\ & 60 \\ 70-100 & 100-200 \\ & 150 \\ 150-300 & 300-400 \\ & 300 \\ 300-400 & 300\end{array}$

Beef cattle

Young sheep and goats

Adult sheep and goats

Pigs

Chickens

300

Turkeys

$300-400$ 
that the pigs given ERP fared marginally worse than those given no P supplement. Kick et $a l^{10}$ have found that rock phosphate levels giving more than 175 and 700 ppm $\mathrm{F}$ in the diet were not safe for pigs and chickens, respectively, even for short-term feeding.

The etiology of $\mathrm{F}$ toxicity (fluorosis) in livestock has been comprehensively discussed by Underwood. ${ }^{15}$ As in the case of the other toxic mineral elements, the maximum safe level of dietary $F$ varies according to the age and species of the animal, the physical and chemical form of the element, the duration and continuity of the intake and the nature and proportions of the other dietary ingredients. Highly soluble F sources like sodium fluoride are much more toxic than highly insoluble sources like calcium fluoride; rock phosphates are intermediate. Table 4 gives the maximum safe dietary levels of $\mathrm{F}$ for various farm animals and $\mathrm{F}$ sources.

Highly effective defluorinating procedures have been developed to reduce the $\mathrm{F}$ content of rock phosphates to safe levels. The degree of heat treatment required to defluorinate rock phosphate is also adequate to convert its $\mathrm{P}$ to the readily available ortho-phosphate form and may sometimes be severe enough to convert some of the ortho-phosphate form to less available pyro- and meta-phosphate forms. ${ }^{15}$ However, there is ample evidence to show that defluorinated rock phosphates are as good as DCP for supplementation of diets for growing chickens, ${ }^{6}$ laying hens, ${ }^{8}$ growing pigs $3,4,7,11$ and growing sheep. 9 The maximum level of residual $F$ in defluorinated rock phosphates for pig feeding is considered to be $0.2 \%{ }^{14}$

\section{Conclusion}

To sum up, ERP as such is unsuitable as a $\mathrm{P}$ supplement for farm animals due to its low $P$ availability and high $F$ toxicity. It is possible to reduce its $F$ content to a perfectly safe level and simultaneously increase the available $\mathrm{P}$ content to that of DCP by an appropriate defluorinating procedure. Defluorinated ERP would be quite comparable with DCP which is now being imported in large quantities for $\mathrm{P}$ supplementation of diets for livestock and poultry. In crop production too, ERP as such is unsuitable for direct application, especially to quick-growing crops ${ }^{16}$ and huge quantities of phosphatic fertilizer have to be imported annually. Technological and agronomic studies have clearly shown that ERP is quite suitable for production of single and triple superphosphates. ${ }^{2}$ These facts taken together warrant the installation of appropriate processing plants for the optimum utilization of ERP in animal and crop production. 


\section{Acknowledgements}

This work was partly supported by a research grant from the Natural Resources, Energy and Science Authority of Sri Lanka. The authors are thankful to Mr Hilary D. Fernando of Christombu Farm and Tea Gardens, Bulathsinhala, for supplying the experimental chicks free-of-charge. The assistance of Mr G. T. S. Ranaweera of the State Piggery, Welisara, in the pig experiment and of Mr E. M. C. Ekanayake of the Veterinary Research Institute, Gannoruwa, in bone analysis is gratefully acknowledged.

\section{References}

1. AEC (1978). Animal Feeding: Document No 4. Societe de Chimie Organique et Biologique, 03600 Commentry, France.

2. AMARASIRI, S. L. (1983). Unpublished data.

3. AMMERMAN, C. B., ARRINGTON, L. R., McCALL, J. T., FEASTER, J. P., COMBS, G. E. \& DAVIS, G. K. (1963). Inorganic phosphorus utilization by swine as measured by an isotope technique. J. Anim. Sci., 22: 890-893.

4. CHAMBERLAIN, C. C. \& GRIFFIN, S. A. (1963). Sources and levels of phosphorus for growing-finishing swine. J. Anim. Sci., 22: 242 (abstract).

5. CORLEY, J. R., BAKER, D. H. \& EASTER, R. A. (1980). Biological availability of phosphorus in rice bran and wheat bran as affected by pelleting. J. Anim, Sci, 50: 286-292.

6. DILWORTH, B. C. \& DAY, E. J. (1964). Phosphorus availability studies with feedgrade phosphates. Poult. Sci., 43 : 1039-1044.

7. HARMON, B. G., CORNEliUS, S. G., BAKER, D. H. \& JENSEN, A. H. (1974). Efficiency of defluorinated phosphate as a supplement in swine rations. J. Anim. Sci., 39: 182-183.

8. HARMS, R. H., DOUGLAS, C. R. \& WALDROUP,' P. W. (1961). The effects of feeding various levels and sources of phosphorus to laying hens. Univ. Fla. Agric. Exp. Sta. Bull., No 644;24pp.

9. HEMINGWAY, R. G. \& FINN, A. M. (1977). Comparative retentions of fluorine and phosphorus by grazing sheep given either defluorinated rock phosphate or dicalcium phosphate of differentparticle sizes. J. Agric. Sci. UK, 89: 683-685. 
10. KICK, C. H., BETHKE, R. M., EDGINGTON, B. H., WILDER, O. H. M., RECORD, P. R., WILDER, W., HILL, T. J. \& CHASE, S. W. (1935). Fluorine in animal nutrition., Obio Agric. Exp. Sta. Bull., No 558; 77 pp. Wooster, Ohio.

11. NEWMAN, C. W. \& ELLIOTT, D. O. (1976). Sources and levels of phosphorus for growing-finishing swine., J. Anim. Sci., 42: 92-98.

12. PHILIPS, P. H., GREENWOOD, D. A., HOBBS, C. S. \& HUFFMAN, C. F. (1960). The Fluorosis Problem in Livestock Production., National Academy of SciencesNational Research Council Publ. No 824. Washingron DC.

13. SNOOK, L. C. (1962). Rock phosphates in stock feeds: the fluorine hazard. Aust. vet. J., 38: 42-47.

14. TOMME, M. F. \& PECHKUVOVA, V. B. (1973). Incompletely defluorinated phosphates in diets for growing pigs. Nutr. Abstr. Rev., 43: 260 (abstract).

15. UNDERWOOD, E. J. (1966). Fluorosis in farm animals. In The Mineral Nutrition of Livestock, pp 187-201. Food \& Agriculture Organization and Commonwealth Agricultural Bureaux.

16. WEERARATNE, C. S. (1979). ${ }^{32} \mathrm{P}$ studies on $\mathrm{P}$ availability in soils incubated with local and imported rock phosphates and concentrated superphosphates. In Isotopes and Radiation in Research on Soil-plant Relationsbips, pp 479-486. International Atomic Energy Agency, Vienna. 